\title{
The effect of supplements of groundnut flour or groundnut protein isolate fortified with calcium salts and vitamins or of skim-milk powder on the digestibility coefficient, biological value and net utilization of the proteins of poor Indian diets given to undernourished children
}

\author{
BY KANTHA JOSEPH, P. K. TASKER, M. NARAYANARAO, \\ M. SWAMINATHAN, A. SREENIVASAN \\ AND V. SUBRAHMANYAN
}

Central Food Technological Research Institute, Mysore, India

(Received 23 October 1961-Revised 17 August 1962)

The production of milk and other protective foods in many tropical and subtropical countries is inadequate to meet the needs of the population (FAO, I959). The diets consumed in these countries are in general deficient in proteins, certain vitamins and minerals (FAO, 1959; Jelliffe, 1955). The problem of providing low-cost supplementary foods based on locally available protein-rich foods of vegetable origin has recently been engaging the attention of research workers (Subrahmanyan, Narayanarao \& Swaminathan, I960; Scrimshaw \& Bressani, I96I) and also of international agencies (Autret \& van Veen, 1955). Among the promising protein sources are oilseed meals and legumes. Groundnut meal is available in large quantities as a by-product of the oil industry in many countries (Altschul, 1958). Joseph, Narayanarao, Swaminathan \& Subrahmanyan (1957) have reported that the incorporation in a poor Indian rice diet of a processed protein food, based on a $3: 1$ blend of low-fat groundnut flour and chick-pea (Cicer arietinum) flour and fortified with calcium salts and vitamins, caused a significant increase in the retention of nitrogen, calcium and phosphorus by children.

The proteins of groundnut contain less lysine, methionine, threonine and tryptophan than milk proteins (Block \& Weiss, 1956). No information is available on the comparative retentions of $\mathrm{N}$ on a poor Indian rice diet supplemented with equal amounts of proteins from groundnut or milk. Therefore the metabolism of N, Ca and $\mathbf{P}$ and the digestibility coefficients and biological value of the proteins and net protein utilization were studied in children receiving a poor rice diet supplemented with the same amounts of proteins, $\mathrm{Ca}$ and $\mathrm{P}$ either from groundnut flour (GF) or groundnut protein isolate (GPI) fortified with $\mathrm{Ca}$ salts and vitamins or from skim-milk powder. The results of experiments with these diets relating to $\mathrm{N}, \mathrm{Ca}$ and $\mathrm{P}$ metabolism have recently been published (Joseph, Tasker, Narayanarao, Sankaran, Swaminathan, Sreenivasan \& Subrahmanyan, 1962). The present paper is concerned with the digestibility coefficient and biological value of the proteins and net protein utilization. 


\section{EXPERIMENTAL}

Materials. The composition of the groundnut flour and groundnut protein isolate fortified with $\mathrm{Ca}$ salts and vitamins and of skim-milk powder fortified with vitamins used in this investigation is given in an earlier paper (Joseph et al. 1962). The contents of essential amino acids in the mixed proteins in the different diets consumed by the children, determined by the method of Krishnamurthy, Tasker, Ramakrishnan, Rajagopalan \& Swaminathan ( 1960 ), are given in Table $\mathrm{I}$ and compared with the FAO reference protein pattern (FAO, 1957).

Table I. Essential amino acid content* $(g / \mathrm{I} 6 g N)$ of the mixed proteins of the different diets

\begin{tabular}{|c|c|c|c|c|c|}
\hline \multirow[b]{2}{*}{ Amino acid } & \multicolumn{4}{|c|}{ Diet } & \multirow[b]{2}{*}{$\begin{array}{c}\text { FAO } \\
\text { (1957) } \\
\text { reference } \\
\text { protein } \\
\text { pattern }\end{array}$} \\
\hline & $\begin{array}{l}\text { Rice } \\
\text { diet }\end{array}$ & $\begin{array}{l}\text { Rice diet + } \\
\text { groundnut } \\
\text { flour }\end{array}$ & $\begin{array}{l}\text { Rice diet }+ \\
\text { groundnut } \\
\text { protein } \\
\text { isolate }\end{array}$ & $\begin{array}{c}\text { Rice diet }+ \\
\text { skim-milk } \\
\text { powder }\end{array}$ & \\
\hline Arginine & $5 \cdot 61$ & $7 \cdot 83$ & $7 \cdot 65$ & 4.83 & - \\
\hline Histidine & $2 \cdot 12$ & $2 \cdot 15$ & $2 \cdot 23$ & $2 \cdot 37$ & - \\
\hline Lysine & $4 \cdot 6 x$ & $3 \cdot 93$ & $3 \cdot 84$ & $6 \cdot 12$ & $4 \cdot 2$ \\
\hline Tryptophan & $1 \cdot 14$ & $1 \cdot 10$ & $x \cdot 12$ & $1 \cdot 33$ & $\mathrm{I} \cdot 4$ \\
\hline Phenylalanine & $5 \cdot 50$ & $5 \cdot 34$ & 5.21 & $5 \cdot 32$ & $2 \cdot 8$ \\
\hline Cystine & $1 \cdot 34$ & I.4I & $x \cdot 38$ & $I \cdot 12$ & - \\
\hline Methionine & $x \cdot 66$ & $1 \cdot 39$ & $1 \cdot 42$ & $2 \cdot 10$ & $2 \cdot 2$ \\
\hline $\begin{array}{l}\text { Total sulphur amino } \\
\text { acids }\end{array}$ & $3 \cdot 00$ & $2 \cdot 80$ & $2 \cdot 80$ & 3.22 & $4 \cdot 2$ \\
\hline Threonine & 3.84 & $3 \cdot 31$ & 3.23 & 4.25 & $2 \cdot 8$ \\
\hline Leucine & $8 \cdot 22$ & $7 \cdot 31$ & $7 \cdot 14$ & $9 \cdot 03$ & 4.8 \\
\hline Isoleucine & 4.93 & 4.54 & $4 \cdot 28$ & $5 \cdot 61$ & $4 \cdot 2$ \\
\hline Valine & 6.42 & 5.84 & $5 \cdot 65$ & $6 \cdot 63$ & $4 \cdot 2$ \\
\hline \multicolumn{6}{|c|}{ Protein score (FAO, 1957) } \\
\hline & $7 \mathbf{I}$ & 67 & 67 & 76 & 100 \\
\hline
\end{tabular}

- The limiting amino acids in bold-faced type.

Metabolic study. The details of the metabolic study have been described by Joseph et al. (1962). The subjects were eight girls aged 8-9 years, belonging to low-income groups. The metabolic study was divided into five periods: period $\mathrm{I}$, rice only (rice diet); period 2, rice + fortified groundnut flour (rice-GF diet); period 3, rice + fortified groundnut protein isolate (rice-GPI diet); period 4, rice + skim-milk powder (rice-SMP diet); period 5, low-protein diet. The children were given a rest for I week between metabolism periods during which they were fed on the basal rice diet. The compositions of the rice diet, rice-GF diet, rice-GPI diet and rice-SMP diet and the analytical methods used have already been described (Joseph et al. 1962). The different protein foods added to the rice diet provided about $20 \mathrm{~g}$ extra protein daily. The low-N diet was similar in composition to that used by Tasker, Doraiswamy, Narayanarao, Swaminathan, Sreenivasan \& Subrahmanyan (1962), and the digestibility coefficient and biological value of the proteins of the diets were calculated by their methods. The net protein utilization (operative) $\mathrm{NPU}_{(\mathrm{op})}$, net dietary protein value 
(ND-pv) and net dietary protein calories \% (ND-p Cals \%) were calculated according to the formulas of Platt, Miller \& Payne (196r).

Definition of terms. The terms were introduced by Platt et al. (196r). NPU $(\mathrm{Np})$ refers to the net protein utilized from the diet as consumed without adjustment for level of protein and the amounts of vitamins and minerals in the diet. It is calculated as

$$
\frac{\text { true digestibility coefficient } \times \text { biological value }}{100} \text {. }
$$

ND-pv refers to the net available protein content of the diet. It is calculated as $\mathrm{NPU}_{(\mathrm{op})} \times$ protein content $(\%)$ of the diet.

ND-p Cals \% refers to the net available dietary protein expressed in terms of protein calories in the diet. It is calculated as $\mathrm{NPU}_{(0 p)} \times$ the percentage of protein calories in the diet.

\section{RESULTS}

The results of measurements of endogenous urinary and faecal $\mathrm{N}$ excretion are given in Table 2 and of the digestibility coefficient, biological value, and net protein utilization in Tables $3-5$.

Table 2. Daily urinary and faecal excretion $(g)$ of nitrogen by the children on the low-protein diet

$\begin{array}{ccccc}\text { Girl no. } & \text { Age (years) } & \text { Urinary } & \text { Faecal } & \text { Total } \\ 1 & 8 & 1.03 & 0.69 & 1.72 \\ 2 & 9 & 1.39 & 0.58 & 1.97 \\ 3 & 8 & 1.01 & 0.71 & 1.72 \\ 4 & 9 & 1.39 & 0.62 & 2.01 \\ 5 & 9 & 1.47 & 0.46 & 1.93 \\ 6 & 8 & 1.04 & 0.92 & 1.96 \\ 7 & 9 & 1.41 & 0.79 & 2.20 \\ 8 & 8 & 1.08 & 0.81 & 1.89 \\ \text { Mean value with } & & 1.23 \pm 0.13 & 0.70 \pm 0.05 & 1.93 \pm 0.09 \\ \text { its standard error } & & & & \\ \text { (7 df) } & & & \end{array}$

Table 3. Digestibility coefficient and biological value of proteins of the different diets eaten by the children

\begin{tabular}{|c|c|c|c|c|c|c|}
\hline \multicolumn{2}{|l|}{ Diet } & \multirow{3}{*}{$\begin{array}{l}\text { Nitrogen } \\
\text { intake } \\
\text { (g/day) }\end{array}$} & & & \multirow{3}{*}{$\begin{array}{c}\text { True } \\
\text { digestibility } \\
(\%)\end{array}$} & \multirow{3}{*}{$\begin{array}{l}\text { Biological } \\
\text { value }\end{array}$} \\
\hline \multirow[b]{2}{*}{ Description } & \multirow{2}{*}{$\begin{array}{c}\text { Calorie } \\
\text { value } \\
\text { (kcal/day) }\end{array}$} & & \multicolumn{2}{|c|}{$\begin{array}{l}\text { Nitrogen excretion } \\
\text { (g/day) }\end{array}$} & & \\
\hline & & & Urinary & Faecal & & \\
\hline Rice & I 394 & 4.08 & $2 \cdot 19$ & $I \cdot 14$ & $89 \cdot 2$ & $73 \cdot 6$ \\
\hline $\begin{array}{l}\text { Rice }+ \text { fortified } \\
\text { groundnut flour }\end{array}$ & 1382 & $7 \cdot 30$ & $3 \cdot 86$ & I 99 & $82 \cdot 2$ & $56 \cdot 0$ \\
\hline $\begin{array}{l}\text { Rice }+ \text { fortified } \\
\text { groundnut protein } \\
\text { isolate }\end{array}$ & I 388 & $7 \cdot 20$ & $3 \cdot 85$ & $x \cdot 68$ & $86 \cdot 3$ & $57 \cdot 8$ \\
\hline $\begin{array}{l}\text { Rice + skim-milk } \\
\text { powder }\end{array}$ & 1372 & $7 \cdot 35$ & 3.37 & $x \cdot 76$ & 85.5 & $65 \cdot 7$ \\
\hline $\begin{array}{l}\text { Standard error of } \\
\text { the mean }(2 \mathrm{df})\end{array}$ & - & - & - & - & \pm 1.92 & $\pm 2 \cdot 42$ \\
\hline
\end{tabular}


Table 4. Mean values for net protein utilization, net dietary protein value and net dietary protein calories with the different diets eaten by the children

\begin{tabular}{|c|c|c|c|c|c|c|c|c|}
\hline \multirow[b]{2}{*}{ Diet } & \multicolumn{2}{|c|}{$\begin{array}{l}\text { Daily protein } \\
\text { intake }\end{array}$} & \multirow[b]{2}{*}{$\begin{array}{l}\text { Protein } \\
\text { in diet } \\
(\%)\end{array}$} & \multirow[b]{2}{*}{$\begin{array}{l}\text { Protein } \\
\text { calories } \\
(\%)\end{array}$} & \multirow[b]{2}{*}{$\mathrm{NPU}_{(\mathrm{op})}$} & \multirow[b]{2}{*}{$\begin{array}{c}\text { Net } \\
\text { available } \\
\text { protein } \\
\text { (g) }\end{array}$} & \multirow[b]{2}{*}{$\begin{array}{l}\text { ND-pv } \\
(\%)\end{array}$} & \multirow[b]{2}{*}{$\begin{array}{c}\text { ND-p Cals } \\
\%\end{array}$} \\
\hline & $\mathbf{g}$ & $\begin{array}{c}\mathrm{g} / \mathrm{kg} \\
\text { body- } \\
\text { weight }\end{array}$ & & & & & & \\
\hline Rice diet & 25.5 & I.5 & $7 \cdot 92$ & $7 \cdot 32$ & $65 \cdot 6$ & $16 \cdot 7$ & $5 \cdot 20$ & 4.80 \\
\hline $\begin{array}{l}\text { Rice }+ \text { fortified } \\
\text { groundnut flour }\end{array}$ & $45 \cdot 6$ & 2.6 & 14.03 & $13 \cdot 20$ & $46 \cdot 1$ & $21 \cdot 0$ & $6 \cdot 47$ & 6.08 \\
\hline $\begin{array}{l}\text { Rice }+ \text { fortified } \\
\text { groundnut } \\
\text { protein isolate }\end{array}$ & $45^{\circ} \circ$ & $2 \cdot 6$ & 13.80 & $12 \cdot 96$ & $49 \cdot 8$ & 22.4 & $6 \cdot 87$ & $6 \cdot 46$ \\
\hline $\begin{array}{l}\text { Rice + skim-milk } \\
\text { powder }\end{array}$ & 45.9 & $2 \cdot 6$ & 13.99 & 13.39 & $56 \cdot 4$ & 25.9 & $7 \cdot 89$ & 7.55 \\
\hline $\begin{array}{l}\text { Standard error of } \\
\text { the mean ( } 21 \mathrm{df})\end{array}$ & - & - & 一 & - & \pm 2.82 & - & 一 & \pm 0.34 \\
\hline
\end{tabular}

* The 'reference' protein requirement of the children calculated according to FAO (1957) amounts to $19.3 \mathrm{~g}$.

Protein scores (Table I). The protein scores of the mixed proteins of the diets containing groundnut flour or groundnut protein isolate (67), calculated by the method of FAO (1957), were lower than that of the rice diet ( 7 I) or the rice-SMP $\operatorname{diet}\left(7^{6)}\right.$.

Endogenous urinary and faecal $N$ (Table 2 ). The mean daily urinary $\mathrm{N}$ was $\mathrm{I} \cdot 23 \mathrm{~g}$ and the mean daily faecal $\mathrm{N}$ was $0.70 \mathrm{~g}$ for the children on the low-protein diet.

Digestibility coefficient and biological value of the protein (Table 3 ). The true digestibility coefficients of the proteins in the different diets were nearly the same and ranged from $82 \cdot 2$ to $89 \cdot 2$. The biological value of the protein in the rice-SMP diet $(657)$ was higher than that in diets supplemented with groundnut protein or groundnut flour $\left(5^{6} \cdot 0\right.$ and $57^{\circ} 8$, respectively).

NPU $($ op) and ND- $p$ Cals \% (Table 4$)$. The NPU $\left({ }_{(o p}\right)$ value for the rice-SMP $\operatorname{diet}(56.4)$ was higher than for the diets supplemented with groundnut flour or groundnut protein isolate (46. I and $49^{\cdot 8}$, respectively). The ND-p Cals $\%$ for the rice $\operatorname{diet}\left(4^{\circ} 80\right)$ was lower than for diets supplemented with different protein foods $(6 \cdot 08-7 \cdot 55)$.

Mean intake and absorption of essential amino acids (Table 5). The amount of essential amino acids absorbed was calculated as amino acid intake $\times$ digestibility cocfficient of the protein $\div 100$, on the assumption that all amino acids were digested and absorbed to the same extent. The results show that the amounts of sulphur amino acids absorbed from the rice diet were lower than those required according to the reference protein pattern suggested by FAO (1957).

\section{DISCUSSION}

The results presented in Tables 4 and 5 show that the net available protein from the rice diet $(16.7 \mathrm{~g} /$ day) did not meet the requirement of $19.3 \mathrm{~g}$ of reference protein calculated according to FAO (1957); on the other hand, the net available protein from 
Vol. I7

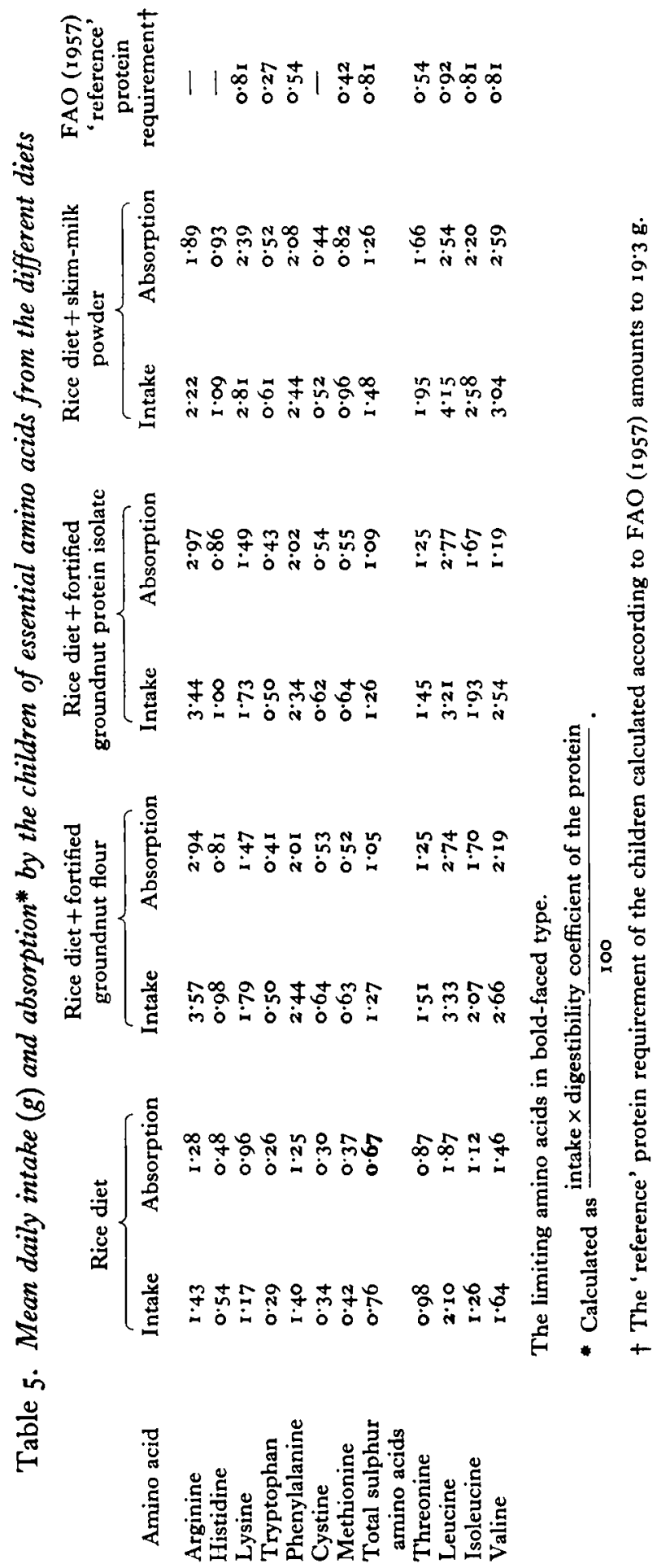

Nutr. I7, I 
the diets supplemented with groundnut flour $(2 \mathrm{I} \cdot \mathrm{g})$ or groundnut protein isolate $(22.4 \mathrm{~g})$ or skim-milk powder $(25.9 \mathrm{~g})$ fully met the protein requirement.

According to Platt $e t$ al. (196I), the protein requirement of girls of the age group $8-9$ years, recommended by FAO ( 1957 ), is about $5 \cdot 9$ when expressed as ND-p Cals $\%$. Judged on this basis, the rice diet did not provide an adequate amount of protein, but after supplementation with groundnut flour, groundnut protein or skim-milk powder it met protein requirement.

\section{SUMMAR Y}

I. The effect of supplementing a poor Indian rice diet with fortified groundnut flour or groundnut protein isolate or skim-milk powder (so as to provide $20 \mathrm{~g}$ extra protein daily) on the biological value and digestibility coefficient of the proteins and net protein utilization was studied in eight girls aged $8-9$ years.

2. The true digestibility coefficients of the mixed proteins in the different diets were nearly the same. The biological value of the proteins of the rice diet supplemented with skim-milk powder was higher than of those in the diets supplemented with groundnut flour or groundnut protein isolate.

3. The $\mathrm{NPU}_{(\mathrm{op})}$ of the diet supplemented with skim-milk powder was greater than of the diets supplemented with groundnut flour or with groundnut protein isolate. The rice diet supplied less, and the protein-supplemented diets more, net available protein than the FAO ( 1957 ) 'reference' protein requirement.

We are thankful to $\mathrm{Mr} \mathrm{A}$. N. Sankaran and Miss K. Indiramma for statistical analysis and to $\mathrm{Mr} \mathrm{V}$. A. Daniel for technical assistance.

\section{REFERENCES}

Altschul, A. M. (editor) (1958). Processed Plant Protein Foodstuffs. New York: Academic Press Inc. Autret, M. \& van Veen, A. G. (1955). Amer. F. clin. Nutr. 3, 234.

Block, R. J. \& Weiss, K. W. (1956). Amino Acid Handbook. Springfield, Ill.: C. C. Thomas.

FAO (1957). F.A.O. nutr. Stud. no. 16.

FAO (1959). Yearb. Food agric. Statist.

Jelliffe, D. B. (1955). W.H.O. Monogr. no. 29.

Joseph, K., Narayanarao, M., Swaminathan, M. \& Subrahmanyan, V. (1957). Brit. F. Nutr. Ir, 388. Joseph, K., Tasker, P. K., Narayanarao, M., Sankaran, A. N., Swaminathan, M., Sreenivasan, A. \& Subrahmanyan, V. (1962). Food Sci. II, 31.

Krishnamurthy, K., Tasker, P. K., Ramakrishnan, 'T. N., Rajagopalan, R. \& Swaminathan, M. (1960). Ann. Biochem. 20, 73.

Platt, B. S., Miller, D. S. \& Payne, P. R. (1961). In Recent Advances in Human Nutrition with Special Reference to Clinical Medicine, p. 351. [J. F. Brock, editor.] London: J. and A. Churchill Ltd.

Scrimshaw, N. S. \& Bressani, R. (1961). Fed. Proc. 20, Suppl. 7, p. 80.

Subrahmanyan, V., Narayanarao, M. \& Swaminathan, M. (r960). Proc. nat. Inst. Sci. India, 26A, Suppl. 1, p. 99.

Tasker, P. K., Doraiswamy, T. R., Narayanarao, M., Swaminathan, M., Sreenivasan, A. \& Subrahmanyan, V. (1962). Brit. Y. Nutr. 16, 36r. 